\title{
Analysis of Pediatric Traumas: Characteristics and the Role of Scoring Systems
}

\section{Pediatrik Travma Vakalarının Analizi: Karakteristikleri ve Skor Sistemlerinin Rolü}

\author{
(1) Hasan Aldinç, (D) Cem Gün
}

Department of Emergency Medicine, Acibadem Mehmet Ali Aydinlar University Istanbul, Turkey

Cite this article as: Aldinç $\mathrm{H}$ Gün C. Analysis of Pediatric Traumas: Characteristics and the Role of Scoring Systems. Bosphorus Med J 2020;7(1):11-15.

Received: 21.08 .2019 Accepted: 18.12 .2019

Correspondence: Dr. Hasan Aldinç. Acıbadem Mehmet Ali Aydınlar Üniversitesi Tıp Fakültesi, Acil Tıp Anabilim Dalı, İstanbul, Turkey

Phone:

+905063976727

e-mail: drhasana@hotmail.com

\section{ABSTRACT}

Objectives: Trauma is a major health problem in the pediatric age group. Various etiological factors can be accounted for the traumas, and they cause significant mortality and morbidity in children. Multiple scoring systems have been developed for evaluating trauma patients. The present study aims to investigate to find out which trauma scoring system used in pediatric trauma is superior to others.

Methods: This retrospective study was conducted in the Emergency Department of a private university hospital that accepts over 200.000 patients annually. Records of all 20314 trauma cases between 0 and 18 years of age, who were referred to ED of a private university hospital in two years, were searched, and 251 of them who were hospitalized evaluated retrospectively. Demographical, etiological, and clinical characteristics, including scores of five trauma scoring systems, were analyzed.

Results: The mean age of the cases was $6.8 \pm 5.4$ years, $86.9 \%$ of the cases had blunt trauma, and $46.9 \%$ had isolated head trauma. The most frequent trauma type was falling from a height (57.3\%), followed by traffic accidents (25.8\%). Mean pediatric trauma score of the patients was $9.41 \pm 1.32$, mean Glasgow Coma Score was $14.79 \pm 0.88$, mean Injury Severity Score was 7.74 \pm 8.44 , mean Revised Trauma Score was 7.84 \pm 0 , mean Trauma Revised Injury Severity Score blunt was $98.45 \pm 7.71$ and mean Trauma Revised Injury Severity Score penetrating was 98.61 \pm 6.90 . The mean duration of the Intensive Care Unit and ward stay was $2.6 \pm 3.1$ and $1.9 \pm 2$ days, respectively, and the total duration of hospitalization was $2.2 \pm 2.7$ days.

Conclusion: The trauma scores provide predictive value for clinical severity and treatment in the initial evaluation of cases at admission to the Emergency Department. In this study, we found that Injury Severity Score and Trauma Revised Injury Severity Score are more valuable than the other scoring systems for determining the patient's length of stay in the hospital.

Keywords: Emergency department; pediatric trauma; trauma score.

\section{ÖZET}

Amaç: Travma, başlıca çocukluk çağı sağlık problemlerindendir ve çoğunluğu önlenebilir özelliktedir. Travma olgularında, mortalite ve morbiditeye belirgin bir şekilde etki eden çeşitli etiyolojik faktör sayılabilir. Travma hastalarını değerlendirmek için birçok skor sistemi geliştirilmiştir. Bu çalışmanın amacı, pediatrik travma hastalarında kullanılan skor sistemlerinin birbirlerine üstünlüğünü incelemektir.

Yöntem: Bu retrospektif çalışma, Acil Servis başvuru sayısı yıllık 200.000 hastanın üzerinde olan bir özel hastanede yapılmıştır. Bu çalışmada, iki yıl boyunca, 0-18 yaş arası travma ile acil servise başvuran 20314 hasta tarandı ve hastaneye yatırılan 251 tanesi retrospektif olarak incelendi. Demografik, etiyolojik ve klinik özellikler ile birlikte beş travma skor sistemi (Yaralanma Ciddiyeti Skoru, Revize Travma Skoru, Travma Revize Yaralanma Ciddiyeti Skoru, Pediatrik Glasgow Koma Skoru, Pediatrik Travma Skoru) analiz edildi. 
Bulgular: Olguların yaş ortalaması $6.8 \pm 5.4$ yaş idi. Olguların $86.9 \%$ 'u künt travma, $46.9 \%$ 'u izole kafa travması idi. En sık görülen travma tipi, yüksekten düşme (57.3\%) idi. Bunu 25.8\% ile trafik kazaları takip ediyordu. Hastaların ortalama Pediatrik Travma Skoru 9.41 \pm 1.32 , ortalama Glascow Koma Skoru 14.79 \pm 0.88 , ortalama Yaralanma Ciddiyeti Skoru 7.74 \pm 8.44 , ortalama Revize Travma Skoru 7.84 \pm 0 , ortalama Travma Revi-

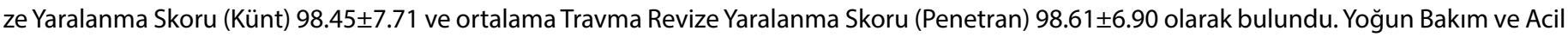
Servis Gözlem yatış süreleri sırası ile ortalama $2.6 \pm 3.1$ ve $1.9 \pm 2$ gün, toplam hospitalizasyon süre ortalaması ise $2.2 \pm 2.7$ gün idi. Hastaneye yatış süreleri, travma skorları ve pozitif görüntüleme bulguları ile korelasyon göstermekteydi.

Sonuç: Acil serviste yatan hastaların ilk değerlendirmesi sırasında klinik ciddiyeti ve gerekli tedaviyi öngörmede travma skorlarının olumlu rolü tespit edildi. Yaralanma Ciddiyeti Skoru ve Travma Revize Yaralan ma Ciddiyeti Skoru'nun hastaların hastanede kalma süresini saptamakta diğer skor sistemlerine göre üstün olduğu tespit edildi.

Anahtar sözcükler: Acil tıp departmanı; pediatrik travma; travma skoru.

$\mathrm{T}$ rauma, which is the most frequent cause of death and disability during childhood, is a preventable condition. [1-4] There are several types of trauma, such as chemical trauma, thermal trauma, and psychological trauma. Physical trauma can be classified according to blunt or penetrating nature. Traffic accidents are the first cause of mortality in Turkey. ${ }^{[3,5]}$ The physiological responses to trauma are different in children when compared with adults. The blood vessels are narrow in children, and they have strong vasoconstriction compensatory responses. Also, multisystem injuries are more frequent in children. Due to these reasons, diagnosis and triage are harder to perform in children. ${ }^{[6]}$

Multiple scoring systems have been developed for evaluating pediatric trauma patients. However, there are not enough superiority studies between these systems in the literature.

In this study, we have evaluated the hospital records of trauma cases between 0-18 years of age, who were referred to the Emergency Department (ED) of a private university hospital and hospitalized for treatment and follow-up monitoring. This study aims to determine which trauma scoring system used in pediatric trauma is superior to others.

\section{Methods}

This retrospective study was conducted in the Emergency Department of Baskent University Adana Hospital which has an annual census of over 200.000 patients. Ethical Committee approval was also obtained from the same university. The inclusion criteria for this study were patients below 18 years of age, patients hospitalized and patients without missing information. The hospital records of 20314 pediatric trauma cases that admitted to the Emergency Department between $1^{\text {st }}$ Jan 2009 to $31^{\text {st }}$ Dec 2010 was searched and 251 of them were hospitalized and they were either monitored, had surgery, transfusion or treated medically. The information collected from the records were age, sex, date, time of admission, type of trauma, consultation notes, imaging studies, Injury Severity Score (ISS), ${ }^{[7]}$ Revised Trauma Score (RTS), ${ }^{[7]}$ Injury Severity Score (TRISS), ${ }^{[7]}$ Pediatric Glasgow Coma Score (GCS), ${ }^{[8]}$ Pediatric Trauma Score (PTS), ${ }^{[7]}$ result of ED admission, hospitalization status, and admission to intensive care unit (ICU).

Descriptive statistics of categorical data were presented as frequency and percent, and numerical data were presented as median, range, mean and standard deviation, where appropriate. Comparisons of non-normally distributed numerical data between independent groups were made using Kruskall-Wallis in more than two groups, and Mann-Whitney $U$ in two groups. Categorical data were compared by Chi-square test. The SPSS ${ }^{\circledR} 21$ (IBM Inc, USA) software was used for the analyses.

\section{Results}

This study included 251 patients (174 boys, 69.3\%; 77 girls, $30.7 \%$ ) with a mean age of $6.8 \pm 5.4$ years. $86.9 \%$ of the cases had blunt, and $13.1 \%$ had penetrating trauma. Majority of the cases had only head trauma (46.9\%), and most frequent period for trauma occurrence was between $5 \mathrm{pm}$ to $12 \mathrm{pm}$ (Table 1).

When the types of traumas were assessed, it was seen that falling from a height was seen with a ratio of $57.3 \%$, and it was the most frequent type of trauma in the study population. Traffic accidents were the second most common cause $(25.8 \%)$, and $83.6 \%$ of traffic accidents were out-vehicle accidents. The findings in imaging studies are shown in Table 2.

A total of 322 consultations were made to the patients. Neurosurgery was the most frequent department for consultations 


\begin{tabular}{lcc}
\hline Table 1. Characteristics of traumas & & \\
& $\mathbf{n}$ & $\%$ \\
\hline Type of trauma & & \\
$\quad$ Blunt & 218 & 86.9 \\
$\quad$ Penetrating & 33 & 13.1 \\
Localization of trauma & & \\
Head only & 107 & 46.9 \\
Limb only & 66 & 28.9 \\
Head+trunk+limb & 17 & 7.5 \\
Trunk only & 17 & 7.5 \\
Head+limb & 10 & 4.4 \\
Head+trunk & 6 & 2.6 \\
Trunk+limb & 5 & 2.2 \\
Time of trauma & & \\
8 a.m.-12 p.m. & 25 & 10 \\
12 p.m.-5 p.m. & 78 & 31.1 \\
5 p.m.-12 a.m. & 107 & 42.6 \\
12 a.m.-8 a.m. & 41 & 16.3 \\
& & \\
\end{tabular}

\section{Table 2. Types of injuries}

\begin{tabular}{lcc} 
& $\mathbf{n}$ & $\%$ \\
\hline Falls & & \\
Falls from a height & 94 & 66.2 \\
Falls from ground level & 48 & 33.8 \\
Traffic accident & & \\
Out-vehicle & 54 & 83.6 \\
In-vehicle & 10 & 16.4 \\
Assault & 5 & 2.0 \\
Firearm injury & 5 & 2.0 \\
Other & 32 & 12.9
\end{tabular}

(39.4\%), followed by orthopedics (24.5\%) and pediatric surgery (23.9\%). Patients were hospitalized most frequently to neurosurgery department (44.6\%), followed by pediatric surgery (20.3\%) and orthopedic surgery (4\%) departments (Table 3).

The mean durations of stays in ICU was 2.6 \pm 3.1 days, in-patient departments 1.9 \pm 2 days, and total duration of hospitalization was 2.2 \pm 2.7 days. Mean pediatric trauma score of the patients was $9.41 \pm 1.32(4.0-12.0)$, mean GCS was $14.79 \pm 0.88$ (7.0-15.0), mean ISS was 7.74 \pm 8.44 (0-75.0), mean RTS was 7.84 \pm 0 (7.84-7.84), mean TRISS blunt was 98.45 \pm .71 (0-99.7) and mean TRISS penetrating was $98.61 \pm 6.90$ (1-99.7). The correlation analyses between trauma scores and hospitalization periods revealed that all scores were statistically significantly correlated with the durations of stays in hospital. The results of the correlation analyses are shown in Table 4.
Table 3. Distribution of departments of consultation and hospitalization

\begin{tabular}{lcc} 
& n & $\%$ \\
\hline Department of consultation & & \\
$\quad$ Neurosurgery & 127 & 39.4 \\
Orthopedics & 79 & 24.5 \\
Pediatric surgery & 77 & 23.9 \\
Ear-nose-throat & 12 & 3.7 \\
General surgery & 9 & 2.8 \\
Plastic surgery & 7 & 2.2 \\
Anesthesia & 7 & 2.2 \\
Cardiovascular surgery & 2 & 0.6 \\
Ophthalmology & 2 & 0.6 \\
Department of the hospitalization & & \\
Neurosurgery & 112 & 44.6 \\
Pediatric surgery & 57 & 22.7 \\
Orthopedics & 51 & 20.3 \\
Ear-nose-throat & 10 & 4.0 \\
Plastic surgery & 7 & 2.8 \\
Anesthesia & 4 & 1.6 \\
General surgery & 4 & 1.6 \\
Cardiovascular surgery & 3 & 1.2 \\
Emergency department & 1 & 0.4 \\
Ophthalmology & 1 & 0.4 \\
& & \\
\hline
\end{tabular}

Table 4. Association of the trauma scores with

hospitalization periods

\begin{tabular}{lcc} 
& $\mathbf{r}$ & $\mathbf{p}$ \\
\hline TRISS penetrating & & \\
ICU+In-Patient & -0.537 & $<0.001$ \\
ICU & -0.461 & 0.004 \\
In-patient & -0.502 & $<0.001$ \\
TRISS blunt & & \\
ICU+In-Patient & -0.547 & $<0.001$ \\
ICU & -0.489 & 0.002 \\
In-patient & -0.520 & $<0.001$ \\
ISS & & \\
ICU+In-Patient & 0.559 & $<0.001$ \\
ICU & 0.552 & $<0.001$ \\
In-patient & 0.531 & $<0.001$ \\
GCS & & \\
ICU+In-Patient & -0.313 & $<0.001$ \\
ICU & -0.313 & $<0.001$ \\
In-patient & -0.314 & $<0.001$ \\
PTS & & \\
ICU+In-Patient & -0.379 & $<0.001$ \\
ICU & -0.372 & $<0.001$ \\
In-patient & -0.369 & $<0.001$ \\
\hline
\end{tabular}

TRISS: Trauma Revised Injury Severity Score; ISS: Injury Severity Score; GCS: Glasgow Coma Score; PTS: Pediatric Trauma Score; ICU: Intensive Care Unit. 


\section{Discussion}

In a previous study that was conducted in 13 trauma centers in United States (US) between 1997-1998, hospitalization due to isolated head trauma was reported to be $18 \%$ of all hospitalizations. ${ }^{[9]}$ In our study, we found that the hospitalization due to isolated head trauma had a proportion of $46.9 \%$, and the mean hospitalization duration was one day for these patients. In another study, the mean duration of hospitalization due to head trauma was found to be 2.9 days. ${ }^{[10]}$ This is similar with the hospitalization of children patients due to head trauma in our university. This relatively high number of days of hospitalization affects the cost and workload, and the indications for hospitalization should be reviewed.

The proportion of the patients with isolated extremity injury was $33 \%$ in the same study, ${ }^{[9]}$ and this was similar to our results of $28.9 \%$. The mean ISS of all patients in the US study was $6.3 \pm 5.9$, and this value was 7.74 in our study. The mean hospitalization duration was 3.3 days in this study, ${ }^{[9]}$ and 2.2 days in our study. Most of the subjects with isolated head trauma had shorter hospitalization periods, and this has lowered our overall hospitalization rates.

In another study, hospitalization due to falling was $23.3 \%$ in pediatric trauma patients. ${ }^{[11]}$ This rate was $57.3 \%$ for our patients. The hospitalization due to traffic accidents was 51.1\% in this study, ${ }^{[11]}$ and $25.8 \%$ in our study. These significant differences may have some causes. The sociocultural level of the environment around our hospital and the diversity of trauma in our ED are determinative of these differences. Moreover, relatively lower hospitalization periods in traffic accidents in our hospital are linked to close follow-up and utilization of evidence-based imaging methods.

Another study from our country, Turkey, reported the distribution of blunt and penetrating trauma as $89.2 \%$, and $10.8 \%$, respectively, and these rates were $86.9 \%$ and $13.1 \%$ in our study. The proportion of traffic accidents in hospitalizations due to trauma was $50 \%$ in that study, which was higher our rate of $25.8 \%$. The in-vehicle and out-vehicle accidents were reported to be $29.7 \%$ and $20.3 \%$, respectively, which was partly different from our results of $4.1 \%$ and $21.7 \%$. The falls from a height constituted $33.8 \%$ of the traumas in that study, which was similar with our $37.9 \%$. The rate of assaults was reported to be $8.1 \%$, whereas it was $2 \%$ in our study population. Firearm injuries were nearly doubled in that study, $4.1 \%$ vs. $2 \%$ in our study. Mean, minimum and maximum days for hospitalization were 4.5 days, 1 day, and 35 days in that study, respectively, and these periods were 2.2, 1 and 21 days in our study. According to their findings, the authors reported that ISS was an independent predictor of hospitalization period $(\mathrm{p}<0.05)$, and it was more valuable in prognostic evaluations of trauma patients when compared to other scoring systems. ${ }^{[12]}$ In our study, we found a correlation between TRISS and ISS and hospitalization periods of the patients ( $\mathrm{p}<0.001)$. Also, GCS and PTS had correlations with hospitalization durations, but it was weaker than the previous ones $(\mathrm{p}<0.001)$. Our results showed that TRISS and ISS were the most appropriate scores in the evaluation of the prognosis of trauma patients

\section{Limitations}

This was a retrospective observational study, and thus, it is possible that some of the important factors that may affect the results were overlooked. For example, physicians who evaluated the study patients could not be standardized about "how to approach trauma patients". The information of the patients before they are admitted to the ED and the reasons for admitting to ED are not known, unfortunately. Also, there is no clear data for the lesions that occurred at the time of trauma.

\section{Conclusion}

Our results revealed the risk factors for pediatric trauma cases as male gender, preschool and primary school age group, 5 pm - 12 pm period, out-of-school environment, and summer months. The most frequent causes of trauma were fallings and traffic accidents, which both can be avoided by legal regulations, centralized monitoring, and social responsibility awareness. The most frequent type of trauma was head trauma. The most frequent department of hospitalization was neurosurgery, and most of these cases were smaller age group patients. The relatively shorter duration of hospitalization in our study population is related to the utilization of advanced imaging methods, and follow-up of the patients by the trauma team, despite we are not a trauma center.

Emergency Physicians do not have a consensus for pediatric trauma patients about hospitalization because there is no standardized protocol has been introduced. ${ }^{[13-15]}$ The trauma scores provide a prediction for clinical severity and treatment in the initial evaluation of cases at admission to ED. In this study, results showed that TRISS and ISS were the most appropriate scores in the evaluation of the prognosis of trauma patients. Determination of the predictive values of 
trauma scoring systems on the survival of the patients will provide better clinical profits for the utilization of these systems. Further studies with larger sample sizes will be useful for elucidating these issues.

\section{Disclosures}

Ethics Committee Approval: The Ethics Committee of Baskent University Medical and Health Sciences Research Board provided the ethics committee approval for this study (B.30.2.B ŞK.0.05.05.05/050.01.08.01-409 - 03.05.2011).

Peer-review: Externally peer-reviewed.

Conflict of Interest: None declared.

Authorship Contributions: Concept - H.A.; Design - H.A.; Supervision - C.G.; Materials - C.G.; Data collection \&/or processing - H.A.; Analysis and/or interpretation - C.G.; Literature search - C.G.; Writing - H.A.; Critical review - C.G.

\section{References}

1. Boomer LA, Nielsen JW, Lowell W, Haley K, Coffey C, Nuss KE, et al. Managing moderately injured pediatric patients without immediate surgeon presence: 10 years later. J Pediatr Surg 2015;50:182-5.

2. Fiorentino JA, Molise C, Stach P, Cinder P, Solla MM, Hoffman E, et al. Pediatric trauma. Epidemiological study among patients admitted to Hospital de Niños "Ricardo Gutiérrez". Arch Argent Pediatr 2015;113:12-20.

3. Öztürk H, Dokucu AI, Otcu S, Onen A. The prognostic importance of trauma scoring systems for morbidity in children with penetrating abdominal wounds: 17 years of experience. J Pediatr Surg 2002;37:93-8.

4. Schlegel C, Greeno A, Chen H, Raees MA, Collins KF, Chung DH, et al. Evolution of a level I pediatric trauma center: Changes in injury mechanisms and improved outcomes. Surgery 2018;163:1173-7.
5. Sathiyasekaran BW. Accident trauma--a descriptive hospital study. J R Soc Health 1991;111:10-1.

6. Ruess L, Sivit CJ, Eichelberger MR, Taylor GA, Bond SJ. Blunt hepatic and splenic trauma in children: correlation of a CT injury severity scale with clinical outcome. Pediatr Radiol 1995;25:321-5.

7. Allen CJ, Wagenaar AE, Horkan DB, Baldor DJ, Hannay WM, Tashiro J, et al. Predictors of mortality in pediatric trauma: experiences of a level 1 trauma center and an assessment of the International Classification Injury Severity Score (ICISS). Pediatr Surg Int 2016;32:657-63.

8. DiBrito SR, Cerullo M, Goldstein SD, Ziegfeld S, Stewart D, Nasr IW. Reliability of Glasgow Coma Score in pediatric trauma patients. J Pediatr Surg 2018;53:1789-94.

9. Segui-Gomez M, Chang DC, Paidas CN, Jurkovich GJ, Mackenzie EJ, Rivara FP. Pediatric trauma care: an overview of pediatric trauma systems and their practices in 18 US states. J Pediatr Surg 2003;38:1162-9.

10. Spencer MT, Baron BJ, Sinert R, Mahmoud G, Punzalan C, Tintinalli A. Necessity of hospital admission for pediatric minor head injury. Am J Emerg Med 2003;21:111-4.

11. McCarthy ML, Serpi T, Kufera JA, Demeter LA, Paidas C. Factors influencing admission among children with a traumatic brain injury. Acad Emerg Med 2002;9:684-93.

12. Narci A, Solak O, Turhan-Haktanir N, Ayçiçek A, Demir Y, Ela Y, et al. The prognostic importance of trauma scoring systems in pediatric patients. Pediatr Surg Int. 2009;25:25-30.

13. Farach SM, Danielson PD, Amankwah EK, Chandler NM. Admission patterns in pediatric trauma patients with isolated injuries. J Surg Res 2015;198:13-8.

14. Ganti L, Conroy LM, Bodhit A, Daneshvar Y, Patel PS, Ayala S, et al. Understanding Why Patients Return to the Emergency Department after Mild Traumatic Brain Injury within 72 Hours. West J Emerg Med 2015;16:481-5.

15. Bonow RH, Quistberg A, Rivara FP, Vavilala MS. Intensive Care Unit Admission Patterns for Mild Traumatic Brain Injury in the USA. Neurocrit Care 2019;30:157-70. 